\title{
School Management of Social Capital Based To Improve Teacher's Performance
}

\author{
Erwin Erlangga ${ }^{1}$, Sugiyo $^{2}$, Haryono $^{3}$, Titi Prihatin ${ }^{4}$ \\ \{erwinerlangga@usm.ac.id', sgy11@mail.unnes.ac.id ${ }^{2}$, fransharyono@mail.unnes.ac.id ${ }^{3}$. \\ titiprihatin.oce@gmail.com $\left.{ }^{4}\right\}$ \\ Universitas Negeri Semarang $g^{1,2,3,4}$
}

\begin{abstract}
Abstrak. This study aimed to explain the management of social capital in MI Annur Losari Brebes to improve the performance of teachers. The method used in this study was a qualitative-descriptive approach. Subjects consisted of cases selected using purposive sampling. The research location was at MI Annur Losari Brebes. The research was carried out with four steps, namely; method of extracting data: observation, interviews, and documentation. Data analysis method used was inductive models. The researchers found that the management of MI schools in Brebes Regency used social capital to improve the teacher's performance in the form of hospitality. Second, social capital management showed a pattern of bridging and strengthening through networking components, mutually beneficial and helpful relationships, and trust. The advantage of this research is that friendship is social capital that can be used to improve school's performance.
\end{abstract}

Keywords: School Management, Social Capital, Teacher Performance.

\section{Introduction}

One of the educational problems faced by Indonesian people is the improvement of the quality of education at every level and the insignificant educational unit, especially in elementary education level $\left[^{1}\right]$. Various efforts have been made to improve the quality of education, including through various trainings and increasing teacher competencies, procurement of books and learning equipment, improvement of educational facilities and infrastructure, and improving the quality of school management $\left[{ }^{2}\right]$. However, various indicators of the quality of education have not shown significant improvement. Some schools show quite encouraging results, but most others are still apprehensive $\left.{ }^{3}\right]$.

In line with the demands of society and global development, education in Indonesia has undergone two very fundamental changes $\left[{ }^{4}\right]$, first, the application of the concept of social capital-based management. By applying this concept, the implementation of education in schools must prioritize social capital and it is hopefully will be more democratic, and the management and coaching of teachers can be adapted to the conditions, demands of the community, and the resources of each school. Second, curriculum changes, from curriculum that emphasize social capital to curriculum $13\left[{ }^{5}\right]$. The curriculum emphasizes that the learning process is based on certain competencies that must be achieved through the learning process. 
Curriculum 13 puts forward a democratic learning process that relies on values, beliefs, norms and rules. Thus, the implementation of the learning process is expected to really guarantee the child becomes active and creative $\left.{ }^{6}\right]$

The application of the concept of social capital-based management and the application of curriculum 13 require changes in teacher's performance $\left[{ }^{7}\right]$. The implementation needs to be carried out comprehensively by empowering teachers and schools. To improve the quality of education formally, aspects of teacher have important roles in realizing it, in addition to other aspects such as facilities / infrastructure, curriculum, students, management, and procurement of books. Teacher is the key to the success of education, because the core of educational activities is teaching and learning which requires the role of the teacher. Many factors influence teacher performance, such as in this research conducted. The results showed that there was a positive and significant influence among education (X1), communication skills (X2) and work motivation (X3) together with performance $\left[{ }^{8}\right]$. The research found that there are positive and significant influences of those three variables toward teacher performance $\left.{ }^{9}\right]$.

The duties and obligations of the principal, besides setting the activities of an educational institution, must also be able to work together and be closely connected to the community. He/ she is obliged to arouse the enthusiasm of staff, teachers and employees to work better, build and maintain kinship, cohesiveness and unity among teachers, employees and students, develop school curriculum, understand school plans and know how to run them, pay attention to and seek for teacher's welfare and so on $\left[{ }^{10}\right]$. Those encourage every organization to further optimize its performance in order to exist and develop according to expectations. Likewise, the leadership of the principal is expected to continue to exist and be able to optimize the performance of the teacher so that it can carry out an activity program that produces qualified education $\left[{ }^{11}\right]$.

In renewing the national education system, a national education vision, mission and development strategy have been established. The vision of education is the realization of the education system as a strong and authoritative social institution to empower and to develop all citizens of Indonesia into qualified human beings so that they are able and proactively respond to the challenges of an ever changing era. Related to this vision, a set of principles has been established to become the basis for implementing education reform [ ${ }^{12}$ ]

One of the principles is that education is held as a process of civilizing and empowering students that lasts for life, where in the process there must be educators who provide exemplary and are able to build willingness, and develop the potential and creativity of students. The implication of this principle is a paradigm shift in the education process, namely from the teaching paradigm to the social capital-based learning paradigm $\left[{ }^{13}\right]$.

\section{Methods}

The approach in this study is classified as qualitative-descriptive research type, because explorative descriptive methods were used in this study. Through exploration, it is expected to be able to get information about the feelings, and aspirations of the subjects in understanding and living their lives. The location of this study was at MI Annur Losari Brebes Regency. In this study, data were divided into two types according to their nature, namely primary and secondary data. The primary data were in the form of key informants, in this case were principals, teachers, staffs, members of foundation, school committees or other data sources in 
the form of certain social situations that were full of information in accordance with the focus of the research.

This primary data were extracted directly from the source at the research location, where MI Annur was located. Primary data collection was done by interviewing key figures (key persons) involved in improving teacher's performance. Secondary data were obtained from the records in the foundation, school committee and school. Besides, it was also obtained from books, theses and articles from newspapers and magazines and on the internet that discussed teacher performance. The informants used here were nonprobability sample. The choice of purposive nonprobability sample was deliberately set because conditions in the field were not possible to reach the entire population. The main instrument used in this study was the author himself using the method of observation, listening and interviewing. The data analysis techniques were:

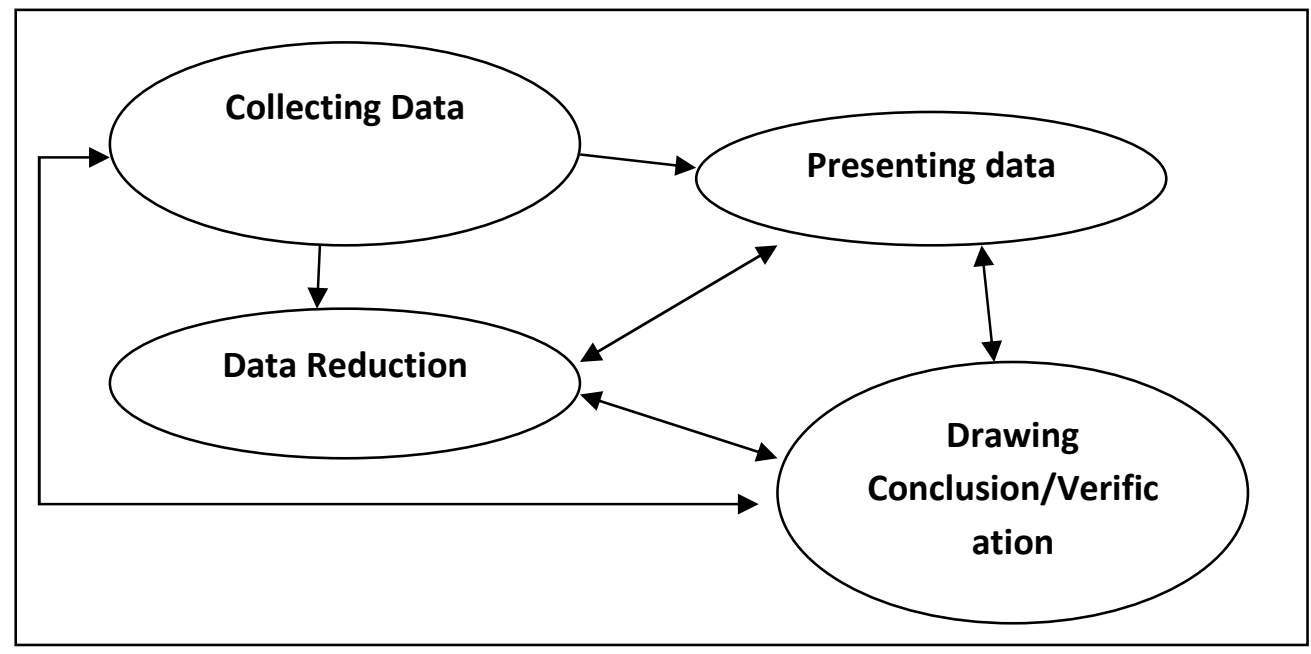

Figure 1. Data Analysis Technique

\section{Results and Discussion}

The results of the study stated that the existence of strong leadership from the head was a requirement to develop the potential of social capital. His activities always share power with staff, so that there is no need to carry out total supervision and inherent in all authority and responsibility $\left[{ }^{14}\right]$. With trust and norms, teachers will perform well due to social capital. From the perspective of several teachers, principals were considered to be quite competent and some of them even stated that the current headmaster was better than the previous ones. The current leadership is considered to work according to procedure, democratic and decisively build social capital. Evaluation is also routinely carried out in the form of routine meetings once a month $\left[{ }^{15}\right]$. While the school principal himself also stated that the organization at MI Annur was very bureaucratic and executed the job description that had been set. So everything goes according to the rules. Furthermore, among principal, vice principals, teachers and staffs work together in jobs that do require teamwork, for example during the accreditation process. This is a manifestation of strong social capital in managing social capital $\left[{ }^{16}\right]$. 
However, there are some lacks in the leadership of the principal in managing social capital. The lacks felt by the teachers were the lack of supervision carried out by the Principal and the lack of mentioned scheduled supervision $\left[{ }^{17}\right]$. MI Annur continues to carry out human resource development programs both internally and externally. Internally, the teachers and staff are always involved in every activity both academic and non-academic so that they will improve their abilities. Externally, the teachers routinely attend MGMP activities and other seminars held by the Government Education Office with funding support from the school. The foundation also provides support for this program in the form of financial support. This is the result of developing social capital $\left[{ }^{18}\right]$.

One of the results shown was the success of two MI Annur teachers who obtained certification from the government due to social capital. However, due to limited funds, the Foundation has not been able to finance all teaching staff to continue their education to higher level (S1 or S2). In terms of quality of learning, the application of the KTSP curriculum runs as it should, although at first it was a bit difficult due to limited time and resources. But, gradually continued efforts were made in the curriculum and the development of questions from the school using social capital $\left[{ }^{19}\right]$.

Teacher is the main driving force of teaching and learning activities at schools. The quality, professionalism and competence of teachers greatly determine the quality of education held in a school. In any educational organization anywhere and everywhere, the teacher's role is very dominant. An increase in teacher's competency from time to time is highly expected, as one of the barometers to improve the quality of education services in a school. Increasing the competence of teachers should include the improvement of pedagogical, personal, social and professional competencies $\left[{ }^{20}\right]$.

Schools that are successful in providing optimal education services to students can be assured of having excellent teachers with competency levels. In the future, teacher's competency should be made as one of the sustainable policy programs in every educational institution including schools. In connection with this, MI Annur continues to strive to improve the quality of its human resources through seminars, MGMP, as well as opportunities for further study $\left.{ }^{21}\right]$. Although the financial support for the development of human resources from the foundation is very limited, the teachers and administrative staff still try to improve their quality by participating in training programs in the MGMP. As a result, two teachers passed the certification $\left[{ }^{22}\right]$.

\section{Conclusion}

The conclusion that can be taken is that hospitality is the social capital in MI Annur Brebes. Teachers are the main activator of teaching and learning activities in schools. The quality, professionalism and competence of teachers greatly determine the quality of education held in a school. In any educational organization, anywhere and everywhere, the teacher's role is very dominant. An increase in teacher performance from time to time is highly expected, one barometer of improving the quality of education services in a school is through social capital. 


\section{Reference}

[1.] Goddard RD. Relational Networks, Social Trust, and Norms : A Social Capital Perspective on Students 'Chances of Academic Success. 2016;25(1):59-74.

[2] Acar E. Effects of Social Capital On Academic Success : A Narrative Synthesis. 2011;6 (June):456-461.

[3]. Lindfors P, Minkkinen J, Rimpelä A, Hotulainen R. Family and School Social Capital, School Burnout and Academic Achievement: a Multilevel Longitudinal Analysis Among Finnish Pupils. Int J Adolesc Youth. 2017;3843:1-14. doi:10.1080/02673843.2017.1389758

[4]. Dematthews D. Community Engagement: A Case Study of an Elementary School in Ciudad Juárez, Mexico.2013. 28(1):167-194.

[5]. Mulford B. Building Social Capital In Professional Learning Communities: Importance, Challenges and a Way Forward. 2007:1-14.

[6]. Gonzalez J. Understanding the Role of Social Capital and School Structure on Latino Academic Success. 2013;2(1).

[7]. Cohen, D Prusak, L In Good Company. How Sosial Capital Makes Organizations Work. Harvard Business Press.2014.28(2):167-178

[8]. Differences I. Social Capital and Student Achievement in Norwegian Secondary Schools. 2008:1-15.

[9] Tokas S. Education and Social Capital. 2016;7(3):257-265. doi:10.5958/2231458X.2016.00026.9

[10]. Ekİncì A. The Effects of Social Capital Levels in Elementary Schools on Organizational Information Sharing. 2012;12(4):2513-2520.

[11]. Takakura M, Hamabata Y, Ueji M, Kurihara A. Measurement of Social Capital at School and Neighborhood among Young People. 2014;10:1-8.

[12]. Bowles S, Ciccone A, Tella R Di, et al. Teaching Practices and Social Capital. 2013;(Putman 1993).

[13]. Huang L, Dămean D, Cairns D. Social Capital and Student Achievement: Exploring the Influence of Social Relationships on School Success in Norway and Romania. 2015;(September):1638-1649.

[14]. Hargreaves ba, fullan m. Of Profession Al With An Investment In Collaboration, Teachers Become Nation Builders. 2013;34(3):36-39.

[15]. Adger, W.N. Sosial Capital, Collective Action, and Adaption to Climate. Economic Change. Economic Change. Economic Geography.2013.79(4),387- 404

[16]. Hargreaves A. School Social Capital and School Effectiveness. Journal Of Social.2010;37:119-136.

[17]. Dervin F. Guanxi , Social Capital and School Choice in China. 2014;56:134-123

[18]. Darwis, M. Guard. Social Capital and Civil Society. Internasional Monetary Fund Working Paper, In Elinor Ostrom And TK ahn.Massachuttes: 2014.80(4),145-245

[19]. Gordon EM, Trygstad PJ, Pasley JD, Banilower ER. How Teachers Develop Social Capital : Illustrative Cases from the Knowles Science Teaching Foundation. 2016;(April).

[20]. Cahuc P, Shleifer A, Algan Y. Teaching Practices and Social Capital. 2011;(6052).

[21]. Catts R, Ozga J. What is Social Capital and how might it be used in Scotland's Schools ?. $2015 ;(36)$.

[22]. Liou T, Chang N. The Applications of Social Capital Theory in Education. 2008;11(September):99-122. 